Arch. Tierz., Dummerstorf 46 (2003) 4, 397-402

University of Kaposvár, Faculty of Animal Science, Hungary

CSABA HANCZ, GÁBOR MILISITS and PÉTER HORN

\title{
In vivo measurement of total body lipid content of common carp (Cyprinus carpio L.) by electrical conductivity
}

\begin{abstract}
A non-destructive method to predict the total lipid content and the lean body mass (LBM) was evaluated by measuring the total body electrical conductivity (TOBEC) with common carp. This technique is based on the principle that body fat and fat-free mass differ in electric properties which can be measured in a low-frequency electromagnetic field. Experimental fish with average body weight of $1225 \pm 298 \mathrm{~g}$ originated from a commercial stock. Fish were slaughtered immediately after the measurements and homogenized samples were taken from the grinded whole-body. The fat content of the homogenates was analysed using Soxhlet extraction after hydrochloric acid digestion. The weight of lean body mass (LBM) was calculated as the difference between the live weight and the weight of fat determined. The TOBEC method provided very precise estimation of lean body mass $\left(\mathrm{R}^{2}=0.99\right)$. Total body lipid content (in gram) can also be predicted from the $\mathrm{E}$ value and live weight with adequate accuracy $\left(\mathrm{R}^{2}=0.66\right)$ in the size range of $706-1989 \mathrm{~g}$ in common carp. The predictibility of the crude fat content (in \%) was moderate $\left(\mathrm{R}^{2}=0.37\right)$ in the present investigation. It could not be increased significantly by including other body measurements as standard lenght, height and circumference. Fat content of table-sized, sexually matured common carp can be estimated at a precision level that may be adequate only if high selection pressure has to be applied in a breeding program.
\end{abstract}

Key Words: common carp, body composition, feeding, body electrical conductivity

\section{Zusammenfassung}

Titel der Arbeit: In vivo Messung des Fettgehaltes von Karpfen (Cyprinus carpio L.) mit Hilfe der elektrischen Leitfähigkeit

Zur Schätzung des Fettgehaltes und des Mager-Körpergewichtes bei Karpfen wurde ein unschädliches Verfahren, die TOBEC-Methode, sie arbeitet mit elektrischem Strom, bewertet. Das Prinzip dieser Methode beruht auf der unterschiedlichen elektrischen Leitfähigkeit von Fettgewebe und den anderen Körpergeweben, die in einem elektromagnetischen Feld bei niedriger Frequenz gut messbar ist.

Die Versuchsfische stammten aus einer Handelspopulation und hatten ein Lebendgewicht von $1225 \pm 298 \mathrm{~g}$. Nach den TOBEC-Messungen wurden die Fische sofort geschlachtet und homogene Muster aus dem ganzen Körper entnommen. Dabei wurde der Fettgehalt mit der Soxhlet-Methode bestimmt. Das Gewicht des mageren Körpers wurde aus der Differenz zwischen Lebendgewicht und Fettgewicht errechnet. Mit der TOBEC-Methode konnte das Mager-Körpergewicht ziemlich gut geschätzt werden $\left(\mathrm{R}^{2}=0,99\right)$. Auch der Fettgehalt des Organismus (in Gramm) kann bei lebenden Karpfen von 706-1989 g entsprechend genau geschätzt werden $\left(\mathrm{R}^{2}=0,66\right)$. Dagegen brachte die Schätzung des Fettgehaltes im Organismus bei diesem Versuch nur ein mittelmäßiges Ergebnis $\left(\mathrm{R}^{2}=0,37\right)$. Eine signifikante Steigerung dieses Wertes wurde auch nicht durch Einbeziehung von Länge, Höhe oder Umfang der Fische erreicht. Es ist also wahrscheinlich, dass die Schätzung des Fettgehaltes im Karpfenkörper nur dann ein entsprechend genaues Ergebnis bringt, wenn Zuchtprogramme mit hohem Selektionsdruck verwendet werden.

Schlüsselwörter: Karpfen, Körperzusammensetzung, elektrische Leitfähigkeit

\section{Introduction}

Assessement of body composition is an important aspect of fish culture and fisheries management. Body composition is traditionally evaluated by chemical proximate analysis, which, of course, requires killing the experimental animals, is an expensive 
and time consuming method. Recently different non-destructive methods are available for determining the body composition (FEKETE, 1992), which allow a fairly good estimation of body composition. One of these methods is the total body electrical conductivity (TOBEC) method, which is based on the different electrical conductivity of fatty and non-fatty tissues and was proven to be successful for predicting lean body mass (LBM) and lipid content in birds and small mammals (CUNNINGHAM et al., 1986; FIOROTTO et al., 1987; FEKETE and BROWN, 1993; STAUDINGER et al., 1995). This rapid, in vivo technique was used for fish at the Texas A\&M University by BROWN et al. (1993), BAI et al. (1994) and JARAMILLO et al. (1994) found significant correlations between TOBEC values and LBM, lipid, water and ash content of sunshine bass, red drum and channel catfish.

High variance of the raw fat content in common carp's fillet was reported by LENGYEL et al. (2001) both in natural waters $(3.1 \pm 3.3 \%)$ and fish ponds $(10.0 \pm 4.5$ $\%$ in Hungary. SCHRENKENBACH et al. (2001) determined the total body composition of a large number of fish originating from lakes and ponds in Germany and found that common carp had very high variance of fat $(8.5 \pm 4.4 \%)$ while protein was quite stable $(13.9 \pm 1.4 \%)$. Substantial genetic variance of carcass value traits, including fat content, was found in Atlantic salmon (RYE and GJERDE, 1996). Common carp was not investigated in this respect, however selective breeding for lower body fat may be an effective way to produce higher valued fish meat and improve feed utilization, because most of the Hungarian carp populations show high (13-19\%) coefficient of variation in fillet fat content (HANCZ et al, 2002).

The objective of the present study was to determine the accuracy of predictions for lean body mass, body fat weight and body fat percentage and to develop prediction equations for the in vivo determination of the total body fat content of common carp by TOBEC.

Materials and methods

Animals and pre-measurement procedure

Experimental fish originated from a commercial stock of table-sized common carp in which both mirror $(\mathrm{N}=27)$ and scaled $(\mathrm{N}=23)$ type was represented. Fish were kept in $1000 \mathrm{~L}$, aerated fiberglass tanks for 14 days prior to measurement, fed on pelleted carp feed at maintainace level (1\%/day) and fasted for the last 48 hours.

TOBEC measurements

The TOBEC measurements were carried out with an EM-SCAN SA-3152 type Small Animal Body Composition Analyser (EM-SCAN Inc., Springfield, Illinois, USA), which allows rapid, non-invasive measurement of the total conductivity index (E value) of small animals. This method is useful for detecting energy absorption in the presence of a radio-frequency electromagnetic field, which is created when a $10 \mathrm{MHz}$ frequency is passed through a copper wire wound around a plexi-glass tube. In this system more energy is absorbed by conductive materials such as normally hydrated lean tissue than by resistant materials such as body fat (FUNK, 1991).

Because the mobility of the animals has a significant effect on the $\mathrm{E}$ values measured (EM-SCAN MODEL SA-3000 OPERATION MANUAL, 1996; MILISITS et al., 1999), fish were anasthetized with Chinaldine that kept them motionless in a lying position during the whole measuring procedure. All fish were carefully blotted dry 
because evaporating water also influences significantly the measured values. E value was determined at least three times and the mean was used for the calculation of prediction equations. Intra-animal variability $(\mathrm{CV})$ of the $\mathrm{E}$ value was lower than $2 \%$ for each animal.

Slaughter and analytical procedures

After the TOBEC measurements recovering fish were over-anasthetized with Chinaldine. Data of body weight, standard length, height and circumference were registered. The sex of fish was determined after dissection then the whole body was diced, grinded and homogenized. About $100 \mathrm{~g}$ sample was taken from each of the homogenates and stored at $-20^{\circ} \mathrm{C}$ until proximate analysis. The crude fat content $(\mathrm{CF})$ of the samples was determined by Soxhlet extraction after hydrochloric acid digestion. The lean body mass (LBM) was calculated as the difference between the body weight and the weight of fat which was determined by chemical analysis.

Statistical procedures

Possible differences between sexes and types (mirror vs. scaled) were tested by independent samples t-test. For the in vivo estimation of fat-free mass, body fat weight and body fat percentage prediction equations were created by linear regression. Observed and predicted values of LBM and lipid content were analyzed by paired ttest. All statistical procedure was carried out using the SPSS statistics software package (SPSS 8.0 FOR WINDOWS, 1997).

\section{Results}

The basic data of the experimental fish are presented in the Table.

Table

Basic data of the experimental fish (Grunddaten des Versuchsfischens)

\begin{tabular}{ccccc}
\hline & \multicolumn{2}{c}{ Males (n=31) } & \multicolumn{2}{c}{ Females (n=19) } \\
Traits & Mean & S. D. & Mean & S. D. \\
\hline Live weight (g) & 1186 & 283 & 1288 & 319 \\
E value & 202 & 70 & 216 & 74 \\
LBM (g) & 1090 & 265 & 1167 & 283 \\
Lipids (g) & 96 & 32 & 119 & 49 \\
Crude fat (\%) & 8.1 & 2.1 & 9.1 & 2.3 \\
\hline
\end{tabular}

"Means are different at $\mathrm{P}<0.05$ level

No significant differences were found comparing traits' means of mirror and scaled carps. The correlation between $\mathrm{E}$ value and lean body mass was examined first and it was found that the $\mathrm{E}$ value in itself gives acceptable precision for estimation of lean body mass (Eq. 1):

$$
\begin{aligned}
& E q .1 . \mathbf{L B M}_{(\mathrm{g}) \mathrm{i}}=381.9+3.566 \mathrm{E}_{\mathrm{i}} \quad\left(\mathbf{R}^{2}=\mathbf{0 . 8 6}, \mathbf{P}<\mathbf{0 . 0 0 1}\right) \\
& \left(\operatorname{LBM}_{(\mathrm{g}) \mathrm{i}}=\text { the weight of lean body mass of the } \mathrm{i}^{\text {th }} \text { animal, } \mathrm{E}_{\mathrm{i}}=\text { the } \mathrm{E} \text { value of the } \mathrm{i}^{\text {th }}\right. \text { animal) }
\end{aligned}
$$

As it was known that body weight shows high correlation with the $\mathrm{E}$ value, involving it into the predicting equation, significantly better accuracy was obtained (Eq. 2):

$$
\text { Eq. 2. } \mathrm{LBM}_{(\mathrm{g}) \mathrm{i}}=42.5+0.780 \mathrm{BW}_{(\mathrm{g}) \mathrm{I}}+3.566 \mathrm{E}_{\mathrm{i}}
$$

$\left(\operatorname{LBM}_{(\mathrm{g}) \mathrm{i}}=\right.$ the weight of lean body mass of the $\mathrm{i}^{\text {th }}$ animal, $\mathrm{BW}_{(\mathrm{g}) \mathrm{i}}=$ the body weight of the $\mathrm{i}^{\text {th }}$ animal, $\mathrm{E}_{\mathrm{i}}=$ the $\mathrm{E}$ value of the $\mathrm{i}^{\text {th }}$ animal)

Applying the same linear regression model to predict the total body lipid content or fat weight, Eq. 3 was received: 


$$
\text { Eq. 3. } \mathbf{C F}_{(\mathrm{g}) \mathrm{i}}=\mathbf{0 . 2 2 0} \mathrm{BW}_{(\mathrm{g}) \mathrm{I}}-\mathbf{0 . 5 8 9} \mathrm{E}_{\mathrm{i}}-42.5 \quad\left(\mathbf{R}^{2}=\mathbf{0 . 6 5 7}, \mathbf{P}<\mathbf{0 . 0 0 1}\right)
$$

Calculated and predicted fat weight show adequately close correlation $(\mathrm{R}=0.806)$ as it can be seen in Figure 1, and paired t-probe also proved the acceptability of this model $(\mathrm{P}=1.0000)$.

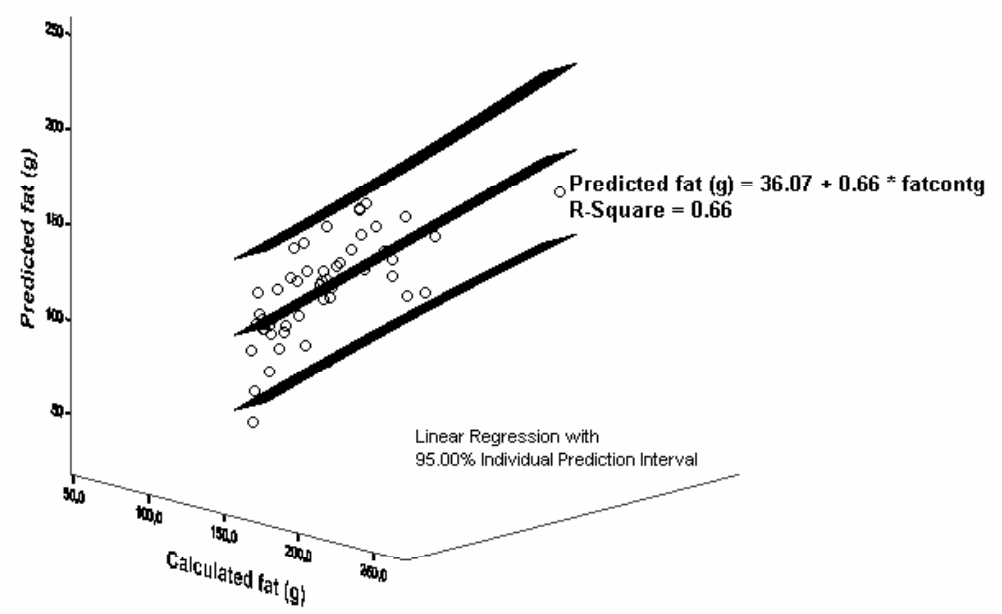

Fig. 1: Correlation between calculated and predicted body fat content (Korrelation zwischen dem kalkulierten und geschätzten Fettgehalt)

When using the same independent variables for predicting the total body fat content in $\%$, the model fitted with lower accuracy (Eq. 4):

$$
\text { Eq. 4. } \mathrm{CF}_{(\%) \mathrm{i}}=4.9+0.010 \mathrm{BW}_{(\mathrm{g}) \mathrm{I}}-0.044 \mathrm{E}_{\mathrm{i}} \quad\left(\mathrm{R}^{2}=0.368, \mathbf{P}<0.001\right)
$$

Calculated and predicted fat $\%$ are less closely correlated $(\mathrm{R}=0.604)$ as it can be seen in Figure 2, but paired t-probe also proved the acceptability of the model $(\mathrm{P}=0.066)$.

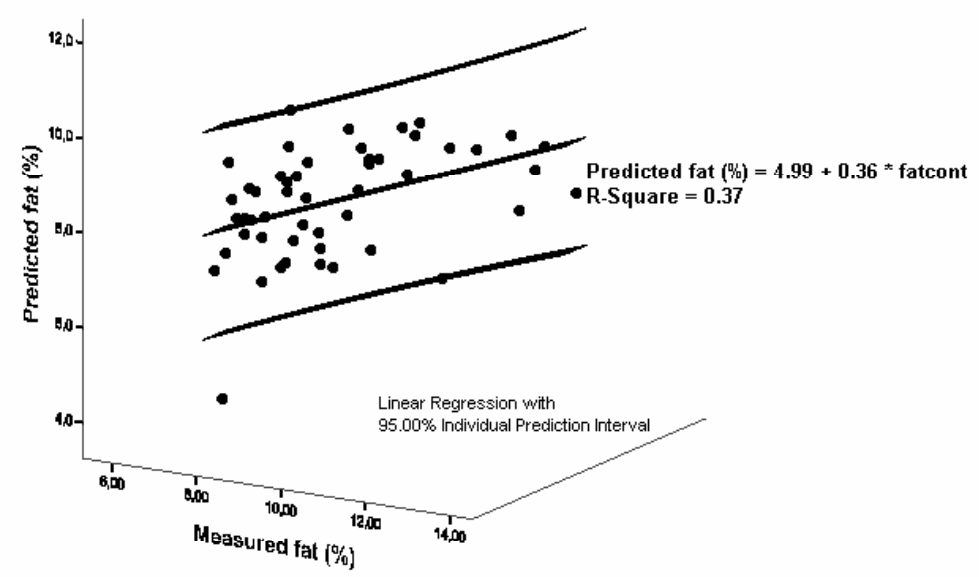

Fig. 2: Correlation between measured and predicted fat content (Korrelation zwischen dem gemessenen und geschätzten Fettgehalt) 
Including all measured variables into the model, the accuracy can be increased $\left(\mathrm{R}^{2}=0.429, \mathrm{P}<0.001\right)$ but this relatively small improvement could be achieved by significantly larger labour expenditure at the measurement process.

\section{Discussion}

Our results on the prediction of LBM are in accordance with the findings of BROWN et al. (1993), BAI et al. (1994) and JARAMILLO et al. (1994), where, similarly to most of the animals investigated, prediction equations of LBM of different fish species had $\mathrm{R}^{2}$ values near to 0.99 .

Lipid content was predicted with much higher accuracy using only the $E$ value $\left(\mathrm{R}^{2}=\right.$ 0.928) in case of sunshine bass (BROWN et al., 1993). JARAMILLO et al. (1994) found that $\mathrm{E}$ value and body weight as independent variables in prediction linear regression model of LBW for channel catfish was produced accuracy of $\mathrm{R}^{2}=0.903$. Lower precision of estimation for common carp can be explained by the fact that, contrary to sunshine bass $(24-124 \mathrm{~g})$ and channel catfish $(44-175 \mathrm{~g})$, investigated carps were sexually matured weighing $706-1989 \mathrm{~g}$ where the connection between fat content (in $\mathrm{g}$ ) and body weight has weaker correlation $(\mathrm{R}=0.685)$. This value was found to be 0.926 in case of the sunshine bass (BROWN et al., 1993).

The TOBEC method seems to be a precise tool for estimating lean body mass also in case of common carp. Total body lipid content (in gram) can be predicted from the $\mathrm{E}$ value and live weight with adequate accuracy $\left(\mathrm{R}^{2}=0.657\right)$ in the size range $706-1989$ $\mathrm{g}$ of common carp. Predictability of the crude fat content (in \%) was moderate $\left(\mathrm{R}^{2}=0.368\right)$ in the present investigation. It could not be increased significantly by involving other body measurements as standard length, height and circumference. However this relatively low $\mathrm{R}^{2}$ can be enough for selectional purposes as it was concluded by LÉVAI and MILISITS (2002) on rabbits.

TOBEC can be a practical, technologically feasible in vivo technique of predicting body composition of common carp, especially in younger age-groups. Fat content of table-sized, sexually matured fish can be estimated at a precision level that may be adequate if high selection pressure has to be applied in a breeding program.

\section{References}

BAI, S.C.; NEMATIPOUR, G.R.; PERERA, R.P.; JARAMILLO JR, F.; MURPHY, B.R.; GATLIN III, D.M.: Total Body Electrical Conductivity for Nondestructive Measurement of Body Composition of Red Drum. The Progressive Fish-Culturist. 56 (1994), 232-236

BROWN, M.L.; GATLIN III, D.M.; MURPHY, B.R.:

Non-destructive measurement of sunshine bass, Morone chrysops (Rafinesque) x Morone saxatilis (Walbaum), body composition using electrical conductivity. Aquaculture and Ficheries Management. 24 (1993), 585-592

CUNNINGHAM, J.; MOLNAR, J.; MEARA, P.A.; BODE H. H.:

In vivo total body electrical conductivity (TOBEC) following perturbations of body fluid compartments in rats. Metab., 35 (1986), 572-575

EM-SCAN MODEL SA-3000 OPERATION MANUAL: EM-SCAN Inc., 1996

FEKETE, S.:

The rabbit body composition: Methods of measurement, significance of its knowledge and the obtained results - a critical review. J. Appl. Rabbit Res., 15 (1992), 72-85

FEKETE, S.; BROWN D.L.:

The major chemical components of the rabbit whole body measured by direct chemical analysis, deuterium oxide dilution and total body electrical conductivity. J. Vet. Nutr., 2 (1993), 23-29 
FIOROTTO, M.L.; COCHRAN, W.J.; FUNK, R.C.; SHENG, H.P.; KLISH, W.J.:

Total body electrical conductivity measurements: effect of body composition and geometry. Am. J. Physiol. (Regulatory Integrative Comp. Physiol. 21) 252 (1987), 794-800

FUNK; R.C..

Electromagnetic scanning: Basis and recent advances in technology. Page 73 in: Proceedings, Symposium on Electronic Evaluation of Meat in Support of Value-Based Marketing, Purdue University, West Lafayette, IN. 1991

HANCZ, C.S.; STETTNER, G.; DEMETERNÉ PÉDERY, T.:

Correlations among growth, feed conversion, body formation and fat content of Hungarian common carp strains. XXVI. Halászati Tudományos Tanácskozás, HAKI. Szarvas. 47-48. (in Hungarian), 2002

JARAMILLO, JR.F.; BAI, S.C.; MURPHY, B.R.; GATLIN III, D.M.:

Application of electrical conductivity for non-destructive measurement of channel catfish, Ictalurus punctatus, body composition. Aquat. Living Resour. 7 (1993), 87-91

LENGYEL, P.; SÁNDOR, ZS.; GYÖRE, K.; SZABÓ, P.; PEKÁR, F.; ZUBCOVA, E.; ALEXIS, M.N.; CSENGERI, I.:

Variations in body composition of common carp and some other Cyprinids according to the feeding. XXV. Halászati Tudományos Tanácskozás, HAKI, Szarvas. 39-40. (in Hungarian) 2001

LEVAI, A.; MILISITS, G.:

Einfluss des nach der TOBEC-Methode bestimmten Fettgehaltes bei Kaninchen auf die Wurfleistungen und die Körperzusammensetzung der Nachkommen. Arch. Tierz., Dummerstorf 45 (2002) 4, 403-411

MILISITS, G.; GYARMATI, T.; SZENDRÖ ZS.: 1999:

In vivo estimation of body fat content of new-born rabbits using the TOBEC method. World Rabbit Science, 7 (1999) 3, 151-154

RYE, M.; GJERDE, B.:

Phenotypic and genetic parameters of body composition traits and flesh colour in Atlantic salmon, Salmo salar L. Aquaculture Research. 27 (1996), 121-133

SCHRENKENBACH, K.; KNÖSCHE, R.; EBERT, K.:

Nutrient content of freshwater fishes. J. Appl. Ichthyol. 17 (2001), 142-144

SPSS FOR WINDOWS,

Version 8.0, Copyright SPSS Inc., 1997

STAUDINGER, F.B.; RORIE, R.P.; ANTHONY, N.B.:

Evaluation of a non-invasive technique for measuring fat-free mass in poultry. Poultry Sci., 74 (1995), 271-278

Received: 2002-11-14

Accepted: 2003-06-12

Author's address

Dr. CSABA HANCZ, Dr. GÁBOR MILISITS, Prof. Dr. PÉTER HORN

University of Kaposvár, Faculty of Animal Science,

Department of Fish and Pet Animal Breeding

P.O.Box 16

H-7401 Kaposvár

Hungary

E-Mail: $\underline{\text { hancz@mail.atk.u-kaposvar.hu }}$ 